\title{
Geologic Sketch of \\ Northwestern Oregon
}

By P. D. SNAVELY, JR., and H. C. WAGNER

CONTRIBUTIONS TO GENERAL GEOLOGY

G E O L O G I C A L S U R V E Y B U L L E T I N 1181-M

A regional summary of the Tertiary

geology in the northern part of the

Oregon Coast Range

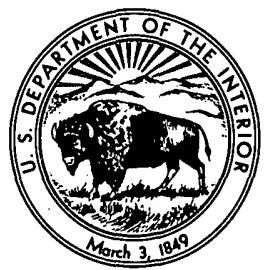





\section{CONTENTS}

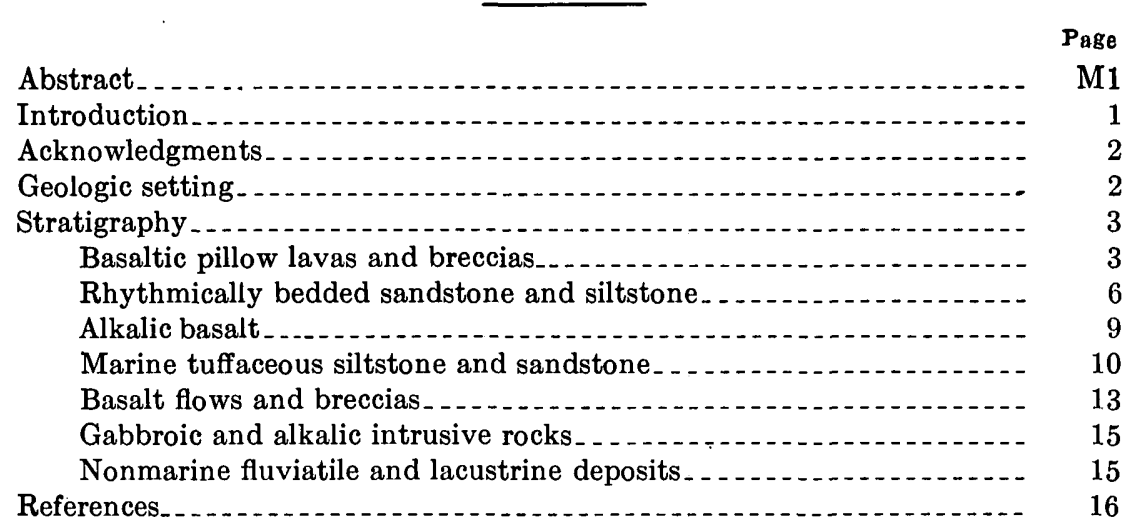

\section{ILLUSTRATIONS}

Plate 1. Generalized geologic and simple Bouguer gravity map of north-

western Oregon. .

Figure 1. Chart showing the correlation between formations in the central and northern parts of the Oregon Coast Range

2. Basaltic pillow. lava with radiating columnar jointing, Siletz River Volcanic Series of early to middle Eocene age .......

3. Generalized composite stratigraphic section of Tertiary rocks, exposed in the Newport embayment, Oregon ...........

4. Rhythmically bedded sandstone and siltstone of the Tyee Formation of middle Eocene age.

5. Boulder and cobble conglomerate overlain by columnar-jointed subaerial alkalic basalt flow of late Eocene age

6. Marine tuffaceous siltstone of middle Oligocene age . . . . _.. 12

7. Massive arkosic sandstone of the Yaquina Formation of late Oligocene age

8. Marine water-laid fragmental basaltic debris of late(?) Miocene age 



\title{
CONTRIBUTIONS TO GENERAL GEOLOGY
}

\section{GEOLOGIC SKETCH OF NORTHWESTERN OREGON}

\author{
By P. D. SNavely, JR., and H. C. Wagner
}

\begin{abstract}
The Tertiary sedimentary and volcanic rocks that crop out in the Coast Range of Oregon have a composite thickness of 25,000 feet and range in age from early Eocene to Pliocene.

The oldest rocks exposed are part of a thick sequence of lower to middle Eocene pillow lavas and volcanic breccias that interfinger complexly with marine tuffaceous siltstone and basaltic sandstone. Although the base is not exposed, the thickness of these rocks is estimated to range from 10,000 to 15,000 feet along the axial part of the Coast Range uplift and to reach 20,000 feet near former centers of volcanism. This volcanic sequence is overlain by $10,000-15,000$ feet of marine sedimentary rocks of middle Eocene to middle Miocene age. These strata consist predominantly of arkosic and lithic wackes with interbedded tuffaceous siltstones and mudstones. Alkalic basalt flows and breccia form thick units within the marine upper Eocene strata. Along the coast, basalt flows and breccia are interbedded with and overlie middle Miocene strata; in the northern part of the map area, subaerial basalt flows, correlative with the widespread middle and late Miocene flood basalts of the Columbia River Plateau, are as much as 1,000 feet thick. Nonmarine fluviatile and lacustrine deposits of late Miocene(?) to Pliocene age are as much as 1,000 feet thick in the structural downwarps in the northern part of the map area.

Sheetlike intrusions of gabbroic and alkalic rocks crop out extensively throughout the southern part of the map area. The thicker gabbroic bodies, which are essentially horizontal and which average $400-500$ feet in thickness were probably emplaced in late Miocene time.
\end{abstract}

\section{INTRODUCTION}

The geology of parts of the Coast Range of northwestern Oregon has been described in numerous publications, but nowhere has a regional summary of the stratigraphy or structure appeared. Therefore, this geologic sketch has been prepared to provide the framework needed to evaluate and interpret new reconnaissance aeromagnetic and gravity data.

A three-dimensional geologic model of the rocks of the Oregon Coast Range is difficult to construct because of the lack of outcrops, which is due to the thick cover of soil and vegetation, and because of 
the paucity of subsurface data. To guide the extrapolation of surface geologic interpretations to depth, geophysical techniques were applied beginning in 1952. The resulting aeromagnetic and gravity measurements supplement surface geological data bearing on the tectonic framework of the area.

The geology of northwestern Oregon, as shown on plate 1, is generalized from the geologic map of Oregon west of the 121st meridian (Wells and Peck, 1961), but it is modified slightly in the central and southern parts of the area as a result of recent mapping by E. M. Baldwin, P. D. Snavely, Jr., and H. C. Wagner.

\section{ACKNOWLEDGMENTS}

The writers' knowledge of the regional geology of western Oregonthe Cascade Range in particular-has been enhanced by numerous discussions with Dallas L. Peck. Peck also critically reviewed the report, as did Thane H. McCulloh; both reviewers made valuable comments. Density determinations on selected surface samples of Tertiary rocks were made by Arthur Conradi.

\section{GEOLOGIC SETTING}

Tertiary sedimentary and volcanic rocks that crop out in the Coast Range of Oregon have a composite thickness of as much as 25,000 feet and range in age from early Eocene to Pliocene. In many parts of the sequence, basalt flows and associated pyroclastic and epiclastic rocks interfinger with the sedimentary sequence and indicate an eventful Tertiary volcanic history. The lower and middle Eocene volcanic and sedimentary rocks were deposited in a rapidly subsiding eugeosyncline that is inferred to have occupied the site of the present Oregon and Washington Coast Ranges, the Olympic Mountains, and the Puget-Willamette lowland. Broad uplifts and volcanic accumulations divided the geosyncline into several separate basins of deposition in the middle part of late Eocene time. A regional unconformity at the base of the uppermost Eocene sedimentary and volcanic sequence indicates this tectonic event. Local unconformities between upper Tertiary formations are common along the margins of lower to middle Eocene volcanic buildups and structural highs; in the basins adjacent to the uplifts, however, deposition of uppermost Eocene and younger strata was essentially continuous, and contacts between formations are gradational in most places.

The general structure of the northern part of the Oregon Coast Range is best described as a northward-plunging anticlinorium in which lower to middle Eocene volcanic rocks are exposed in the structurally highest parts (pl. 1). These rocks, together with the overlying middle Eocene sedimentary rocks, have been folded into 
numerous broad, elongate anticlines and synclines that trend generally northeast in the southern part of the map area and northwest in the northern part. Upper Eocene and lower to middle Oligocene strata dip homoclinally off both flanks of the uplift whereas marine upper Oligocene and Miocene rocks are confined to the west flank except where a marine embayment extended into the northern part of the Willamette Valley.

The principal faults recognized in the area are high-angle normal and reverse faults that commonly trend northwestward or northeastward and have displacements ranging from a few feet to several thousand feet. Recent mapping (1960-62) by Snavely and Wagner in the central part of the Oregon Coast Range suggests that west- to northwest-trending faults with lateral separation (strike slip) may be more common than was previously recognized.

\section{STRATIGRAPHY}

\section{BASALTIC PILLOW LAVAS AND BRECCIAS}

The oldest rocks exposed in the Coast. Range of Oregon are a thick sequence' of lower to middle Eocene ${ }^{1}$ basaltic pillow lavas and volcanic breccias that interfinger complexly with marine tuffaceous siltstone and basaltic sandstone. These volcanic rocks are referred to the Siletz River Volcanic Series (Snavely and Baldwin, 1948) in the southern half of the map area and to part of the Tillamook Volcanic Series (Warren and others, 1945) in the northern half (fig. 1). 'The area of outcrop of the Tillamook Volcanic Series has not been mapped in detail, and it may include flows of late Eocene age in the upper part.

The predominant rock type in the Siletz River Volcanic Series is dark-greenish-gray aphanitic to porphyritic augite-rich basalt, which is commonly amygdaloidal. Well-defined ellipsoidal pillow structures with radiating columnar joints are common (fig. 2), and in places pillow flows grade laterally into massive breccia. Flow breccia and zeolite-cemented extrusive breccia ${ }^{2}$ form thick units within the sequence. Flows and breccias generally contain veinlets of calcite and zeolite minerals. The volcanic glass in the chilled borders of the pillows and in the fragmental material that fills the interstices between the pillows is commonly devitrified to palagonite, celadonite, and (or) greenish montmorillonitic clay.

Water-laid fragmental basaltic debris in the Siletz River Volcanic Series ranges from fine tuff to volcanic breccia; lapilli tuff is the most

\footnotetext{
1 Foraminiferal and molluscan fossils collected from the marine tuffaceous siltstones and basaltic sandstones in the upper part of the Siletz River Volcanic Series in the type area indicate correlation with the middle Eocene Ulatisian Stage of Mallory (1959) (W. W. Rau, written communication, 1962) and the middle Eocene Domengine Stage of California (Weaver and others, 1944) (F. S. MacNell, written commun., 1959).

${ }^{2}$ Rapid quenching of basalt extruded upon the sea floor caused extreme fragmentation. Much of the brecclated material was carried into deeper water by submarine landslides and turbidity currents.
} 


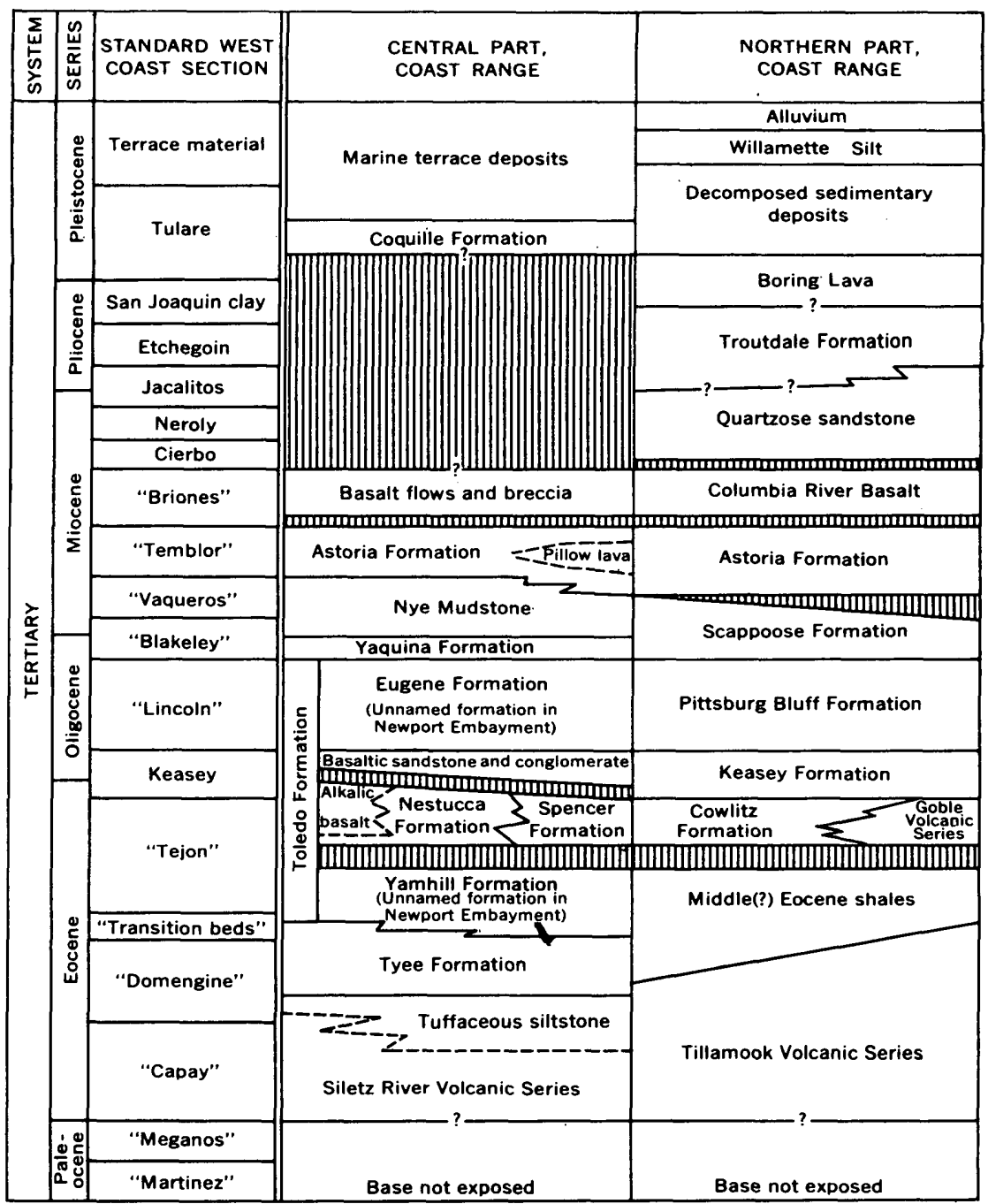

Figure 1.-Chart showing the correlation between formations in the central and northern parts of the Oregon Coast Range. Standard west-coast section from Weaver and others (1944); central part, Coast Range, section modifled after Vokes and others $(1949,1954)$ and from Snavely and Vokes (1949); northern part, Coast Range, section modified after Warren and others (1945).

common. Thin-bedded fossiliferous tuffaceous siltstone and massive basaltic sandstone and conglomerate are intercalated with and overlie the volcanic rocks. In most places the sedimentary interbeds are too thin to be mapped separately; but in the northwestern part of the Corvallis and Euchre Mountain quadrangles, thick tuffaceous siltstones in the upper part of the Siletz River Volcanic Series form mappable units. The marine interbeds contain a molluscan and 


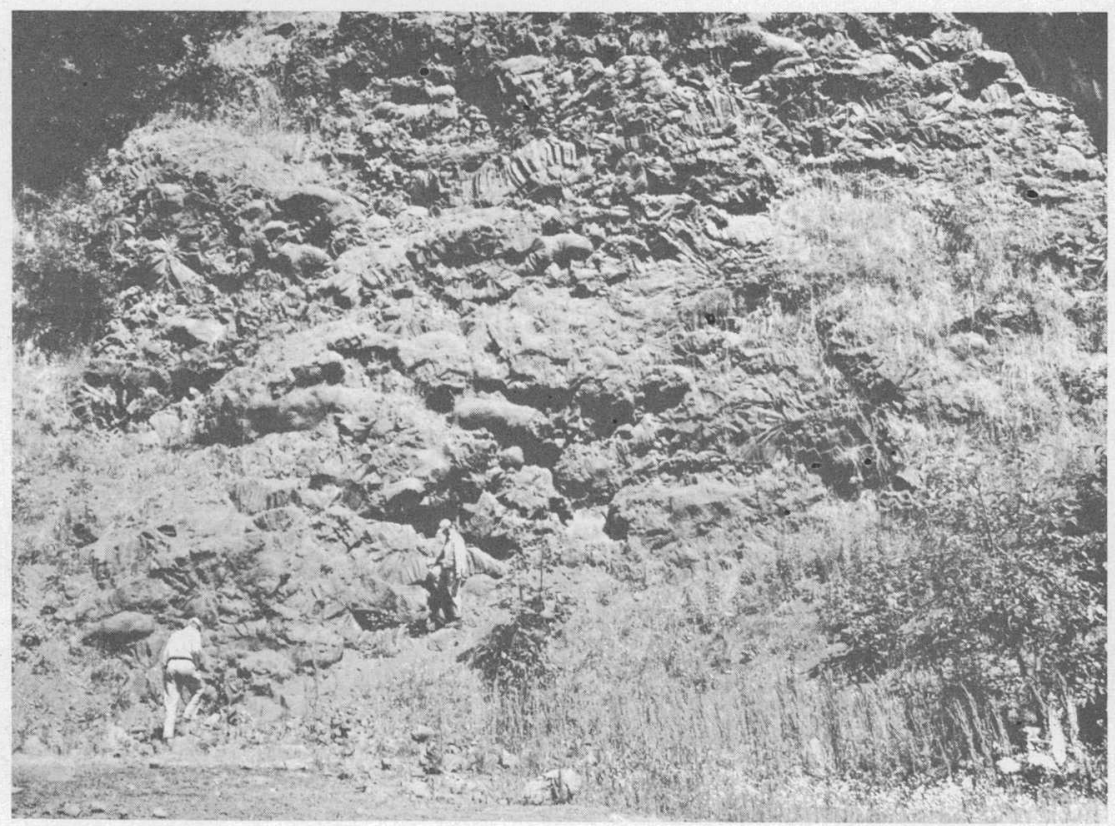

Figure 2.-Basaltic pillow lava with radiating columnar jointing, Siletz River Volcanic Series of early to middle Eocene age. Widow Creek quarry, State Highway 18, near Rose Lodge, Oreg.

foraminiferal fauna that indicates an age equivalent to the Capay Stage of California in the Corvallis quadrangle and a Capay to Domengine age in the Euchre Mountain quadrangle.

The area underlain'by the Tillamook Volcanic Series was a locus of volcanism, largely submarine, from early to middle, and possibly to late, Eocene time. Southward from this area, middle and upper Eocene volcanic rocks intertongue with marine sediments. Immediately south of lat $45^{\circ} \mathrm{N}$. in the Ball Mountain area, field evidence indicates that the extrusion of basalt of the Siletz River Volcanic Series was rapid and extensive enough to build up masses of basalt above sea level. The base of the lower to middle Eocene volcanic rocks is not exposed in the Oregon Coast Range, but a minimum thickness of more than 5,000 feet can be measured in several areas. In the Olympic Peninsula of northwest Washington, where the base of a correlative volcanic sequence (Crescent Formation) is exposed, lower(?) and middle Eocene volcanic rocks have a measured thickness of 15,000 feet on the north side of the peninsula and apparently have and even greater thickness on the east side. Therefore, a reasonable estimate for the thickness of the volcanic sequence in the map area is $10,000-15,000$ feet along the axial part of the uplift and possibly 20,000 feet near former centers of volcanism, as in the Tillamook 
Highlands and Ball Mountain areas. In the map area, the thick volcanic sequence probably thins outward from each of the centers of volcanism; it is much thinner, for example, beneath the Willamette Valley.

Dry bulk density measurements made on 42 surface samples of the

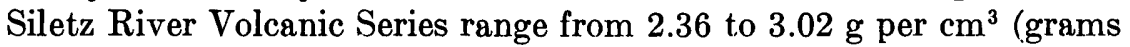
per cubic centimeter) (fig. 3). Volcanic rock types included in these determinations were amygdaloidal, vesicular, and massive flows; feeder dikes and sills; volcanic breccias; and tuffs. The relative proportions of these rock types in the lower to middle Eocene stratigraphic sequence are such that a density of $2.8 \mathrm{~g} \mathrm{per} \mathrm{cm}^{3}$ is believed to represent the average of the formation.

A density contrast of $0.1 \mathrm{~g}$ per $\mathrm{cm}^{3}$ is assumed to occur between the Siletz River Volcanic Series and the pre-Eocene (Cretaceous?) rocks that probably underlie the lower to middle Eocene volcanic sequence throughout the Oregon and Washington Coast Ranges. The nearest outcrops of marine sedimentary rocks of Late Cretacenus age occur in erosional remnants in the Klamath Mountains to the south of the map area. These rocks consist predominantly of sandstone and contain minor amounts of siltstone; they probably are shelf or deltaic facies. Northward, however, the Cretaceous basin of deposition deepened, and the map area is in the part of the basin in which predominantly fine-grained clastic rocks would be expectable. If such fine-grained rocks were present, they would probably be similar to the argillite and graywacke sequence that underlies volcanic rocks of the Crescent Formation in the Olympic Peninsula of western Washington. An average density of $2.7 \mathrm{~g}$ per $\mathrm{cm}^{3}$ was obtained for these pre-Crescent rocks (Stuart, 1961).

\section{RHYTHMICALLY BEDDED SANDSTONE AND SILTSTONE}

Rhythmically bedded marine sandstone and siltstone of middle Eocene age have a wide areal distribution and a thickness of as much as 10,000 feet throughout the southern part of the Oregon Coast Range. This predominantly sandstone sequence, which is referred to the Tyee Formation (Diller, 1898), is confined to the axial part of the Coast Range uplift in the southern half of the map area (pl. 1); there in most places it overlies the Siletz River Volcanic Series with apparent disconformity.

The Tyee Formation consists of graded units 2-10 feet thick which contain bluish-gray medium-grained micaceous arkosic and lithic wackes in their lower parts and grade upward into carbonaceous siltstone (fig. 4). The base of each recurrent graded unit is sharply defined and contains casts of sedimentary structures; groove casts are the most common, but flute casts occur locally. In places the 


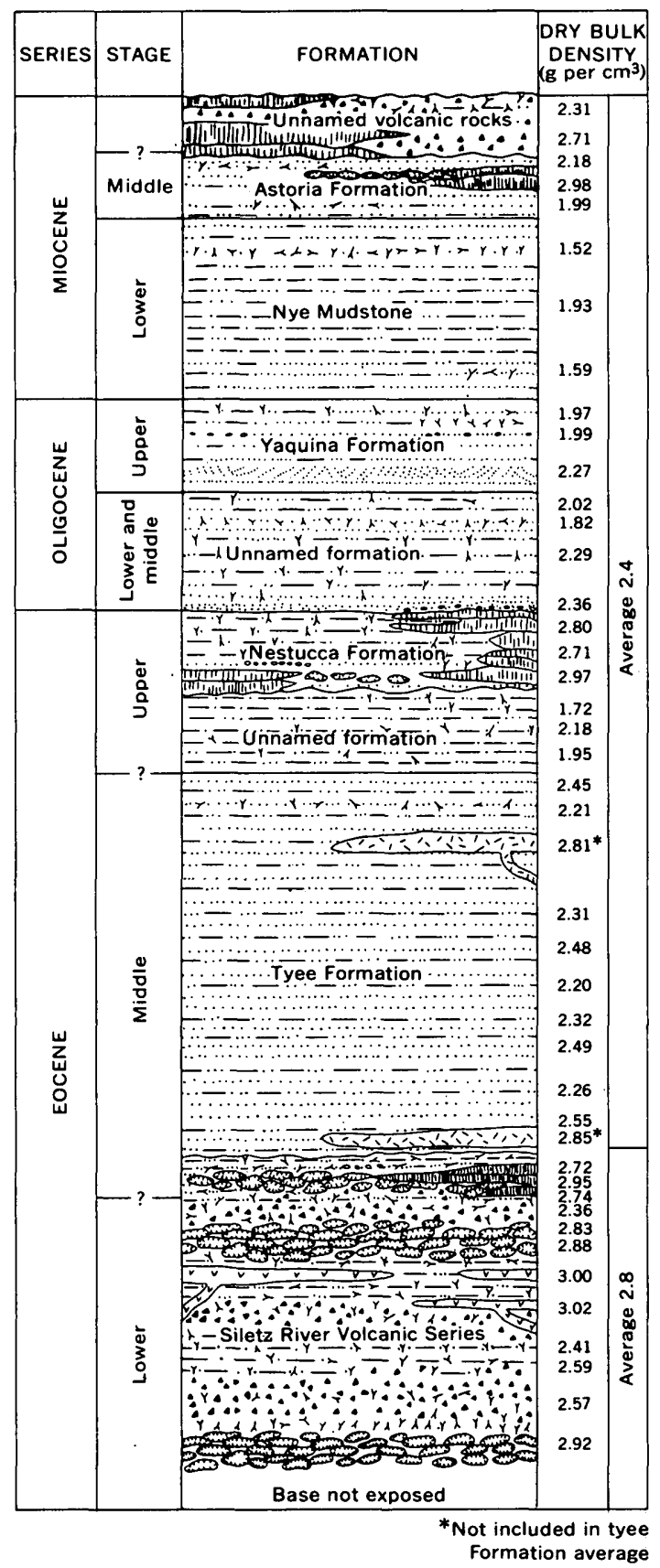

\section{EXPLANATION}

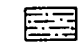

Mudstone

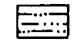

Siltstone

r...7

Tuffaceous siltstone

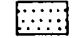

Sandstone

$7 \mathrm{~A}$

Crossbedded sandstone

$\because \therefore$

Conglomerate

$\lambda+x$

?....

Water-laid fragmental basaltic debris

$\because \because$

Flow breccia

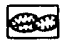

Submarine basaltic pillow lavas

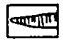

Subaerial basalt flows

\section{vov}

Feeder sills or dikes of basalt

公

Granophyric gabbro intrusives

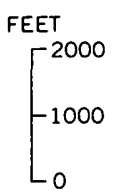

Figure 3.-Generalized composite stratigraphic section of Tertiary rocks exposed in the Newport embayment, Oregon, showing representative density determinations for surface samples. 


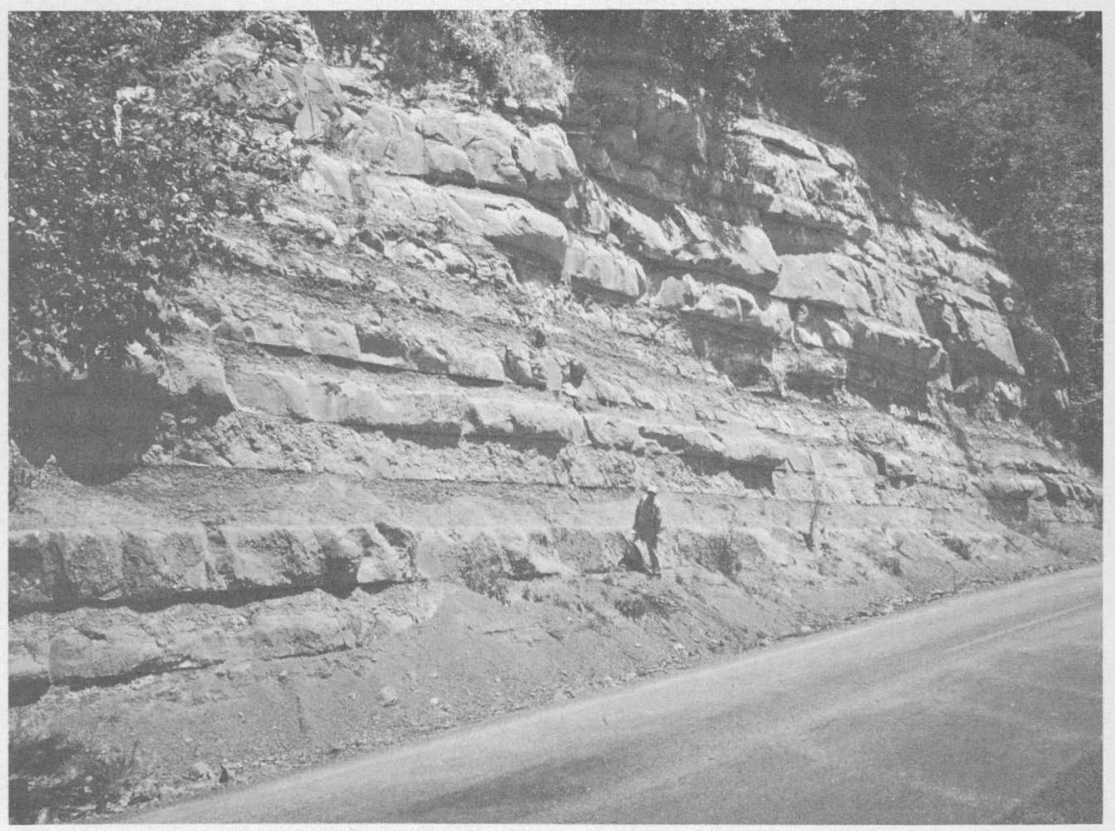

FIGURE 4.-Rhythmically bedded sandstone and siltstone of the Tyee Formation of middle Eocene age. Roadcut exposure along the Siletz River between the towns of Siletz and Kernville, Oreg.

siltstone in the upper part of the graded unit has been stripped off by the current that transported the detritus represented in the overlying rhythmite. Intraformational breccia and subrounded siltstone clasts are common in the sandstone. Both the composition of the sandstone and the paleocurrent directions based on sedimentary structures suggest that the principal source for sediments of the Tyee was an igneous and metamorphic terrane to the south in the area of the present Klamath Mountains (Snavely and Wagner, 1963).

North of lat $45^{\circ} \mathrm{N}$. the sandstone of the Tyee Formation grades laterally into well-indurated dark-gray tuffaceous siltstone and waterlaid pyroclastic rocks. The northern part of the Oregon Coast Range has not been mapped in sufficient detail to separate this middle Eocene argillaceous sequence from the overlying siltstone of late Eocene age. Therefore, for this area, the middle Eocene siltstone is included with the marine sedimentary rocks of late Eocene through Miocene age on the geologic map (pl. 1).

Marine siltstone interbeds in the upper part of the Tyee Formation contain molluscan and foraminiferal faunas correlative with those of the Domengine Stage (middle Eocene) of California.

Measurements made on 58 samples of Tyee siltstone and sandstone

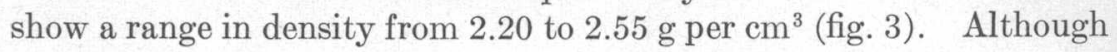


the sandstone-siltstone ratio in the Tyee Formation varies both laterally and vertically in the sequence, the unit as whole is predominantly sandstone, and a density of $2.4 \mathrm{~g}$ per $\mathrm{cm}^{3}$ probably most closely approximates the average density of the formation.

\section{ALKAJIC BASALT}

A sequence consisting predominantly of porphyritic basaltic flows and containing less abundant breccia and water-laid pyroclastic rocks is intercalated with marine tuffaceous siltstone of late Eocene age. ${ }^{3}$ Although in places these upper Eocene volcanic rocks may have extended across the Coast Range uplift, they are now chiefly restricted to the flanks. This volcanic sequence is particularly well exposed along the coast in the southwestern part of the map area (pl. 1); there it has a maximum thickness of 1,500-2,000 feet. These rocks in places include chaotic mixtures of pillow lava, breccia, conglomerate, and siltstone which resulted from the eruption of basalt from numerous centers onto the floor of a relatively shallow marine basin. Islands were formed where the volcanic accumulations were thickest, and much of the sequence was erupted on land (fig. 5).

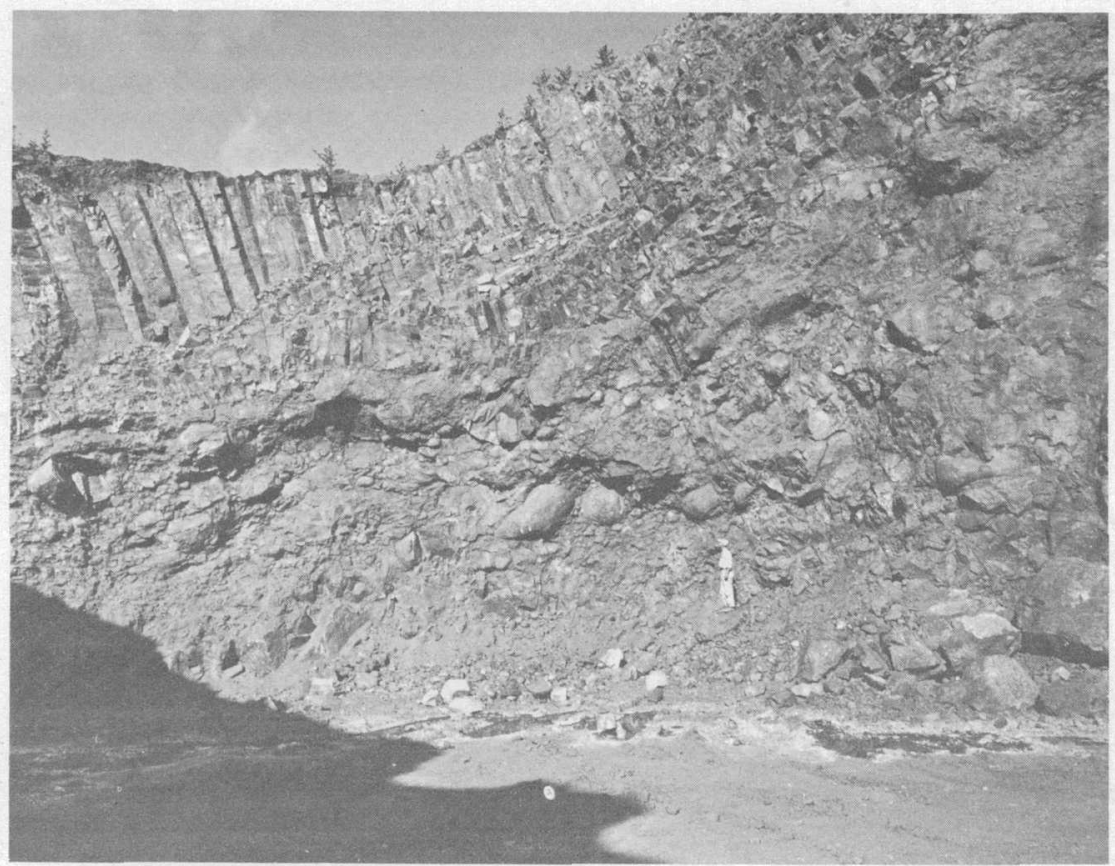

Figure 5.-Boulder and cobble conglomerate overlain by columnar-jointed subaerial alkalic basalt flow of late Eocene age. Eckman Creek quarry, 3 miles southeast of Waldport, Oreg.

\footnotetext{
${ }^{3}$ Recent mapping by Snavely and Wagner in the vicinity of Heceta Head indicates that at least one flow in this sequence is interbedded with lowermost oligocene strata.
} 
In the southern part of the map area, this volcanic sequence is interbedded with tuffaceous siltstone of the Nestucca Formation of late Eocene age (Snavely and Vokes, 1949; Baldwin and others, 1955). Warren and others (1945) included part of these upper Eocene volcanic rocks in their Tillamook Volcanic Series; however, most of these rocks have been shown separately by Wells and Peck (1961). Between the Tillamook Highlands and lat $45^{\circ}$ N., volcanic rocks of late Eocene age are intimately associated with tuffaceous marine sedimentary rocks, but they have not been mapped separately. In the northeast corner of the map area (pl. 1), an estimated thickness of more than 5,000 feet of porphyritic basalt flows, breccia, and pyroclastic rocks of late Eocene age is exposed along the Columbia River. These rocks have been referred to the Goble Volcanic Series (Warren and others, 1945; Wilkinson and others, 1946).

The flows of late Eocene age are dominantly dark-gray porphyritic and aphanitic andesine basalt. These flows are commonly less than 20 feet thick, are massive to platy, and rarely exhibit pillow structure. Density measurements made on 15 samples of upper Eocene basalts indicate a range in density from 2.45 to $2.97 \mathrm{~g} \mathrm{per} \mathrm{cm}^{3}$ and an average density of $2.8 \mathrm{~g}$ per $\mathrm{cm}^{3}$.

\section{MARINE TUFFACEOUS SILTSTONE AND SANDSTONE}

As much as 10,000 feet of marine sedimentary rocks of late Eocene to middle Miocene age is shown as a single unit on the geologic map. The individual formations that constitute this unit are not differentiated because their gross physical properties are similar, and they can be treated as a unit in geophysical analyses of crustal structures.

The dominant lithology of strata of late Eocene age is dark-gray thin-bedded tuffaceous siltstone and massive mudstone. Many of these rocks are rich in organic material; locally they contain limy nodules and glauconite. In many places the sequence contains interbedded friable arkosic and basaltic sandstone, and clastic dikes and sills of sandstone are abundant. Near volcanic centers of late Eocene age, the siltstone contains interbedded alkalic basalt flows and water-laid fine tuff and lapilli tuff. Typical of this sequence are the Nestucca Formation (Snavely and Vokes, 1949) along the coast and the Yamhill Formation along the west side of the Willamette Valley (Baldwin and others, 1955). Abundant Foraminifera in these formations indicate that the Nestucca Formation is equivalent in age to the upper part of the Narizian Stage of Mallory (1959) whereas the Yamhill Formation is early Narizian (W. W. Rau, written commun., 1963). 
The predominantly nearshore marine strata of late Eocene age that crop out along the east flank of the Coast Range uplift in the southeastern part of the map area are referred to the Spencer Formation (Turner, 1938). This formation is characterized by massive to thin-bedded micaceous arkosic sandstone and less abundant siltstone, tuff, carbonaceous siltstone, and lignite. These strata interfinger eastward with a heterogeneous sequence of continental pyroclastic rocks, breccia, and lava flows of andesitic composition (pl. 1, section $\left.Y-Y^{\prime}\right)$.

Marine sedimentary rocks of late Eocene age, assigned to the Cowlitz Formation by Warren and others (1945), generally flank the northern part of the Tillamook Highlands. The formation contains basaltic boulder conglomerate and a few thin basalt flows at the base and grades upward through basaltic sandstone into dark-gray locally glauconitic claystone and tuffaceous siltstone.

In the central part of the Coast Range, a major unconformity separates strata of latest Eocene age from older rocks (fig. 1). The alkalic basalt flows (p. M9-M10) are interbedded with the uppermost Eocene strata that lie above the unconformity. In many places the unconformity is readily apparent since uppermost Eocene sedimentary rocks overlap older strata and rest locally on lower to middle Eocene volcanics. However, where uppermost Eocene siltstone unconformably overlies upper Eocene siltstone, the unconformity is difficult to discern.

Marine Oligocene sedimentary rocks characterized by a high proportion of volcanic ash are widely distributed in the northern part of the map area and along both flanks of the Coast Range uplift farther south. The eastern boundary of marine Oligocene deposition roughtly parallels the low foothills of the Cascade Range, which adjoin the eastern margin of the map area. Along this boundary, marine strata intertongue with continental deposits consisting of dacitic and andesitic tuff, volcanic breccia, and lava flows of andesitic and basaltic composition (Peck and others, 1964).

The predominant lithology of beds of Oligocene age in the Oregon Coast Range is massive to thick-bedded tuffaceous siltstone and finegrained sandstone (fig. 6). Beds of pumice lapilli tuff and glauconitic sandstone are common, and limy nodules and concretions occur locally. Typical of these Oligocene strata are the richly fossiliferous Eugene Formation (Smith, 1924 ; Schenck; 1927) in the southeastern part of the map area, the upper part of the Toledo Formation (Vokes and others, 1949) in the southwestern part, and the Pittsburg Bluff Formation. (Schenck, 1927) in the northern part (fig. 1).

A unit of boulder conglomerate and dark-gray fossiliferous pebbly basaltic sandstone containing interbeds of dark-gray sandy siltstone 


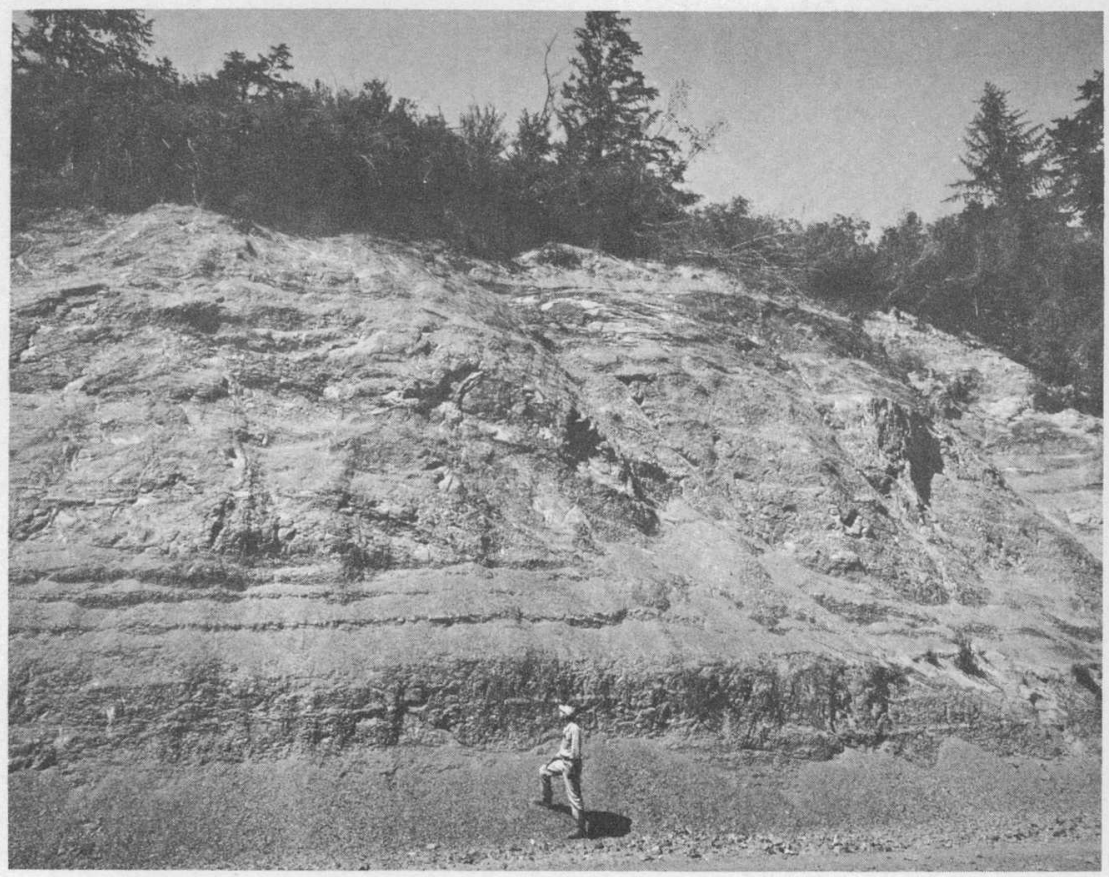

Figure 6.-Marine tuffaceous siltstone of middle Oligocene age. Roadcut on north side of Alsea Bay, $1 \frac{1}{2}$ miles north of Waldport, Oreg.

crops out near the base of the Oligocene sequence in many parts of the Coast Range. The basaltic debris in this unit was derived from erosion of Eocene volcanic highs within the basin of deposition. Wellpreserved mollusks and Foraminifera, indicative of the Keasey Stage of Weaver and others (1944), occur in the sequence.

Strata of late Oligocene age are generally restricted to the west flank of the Coast Range uplift and to an arcuate outcrop belt on the north side of the Tillamook Highland. Most of these strata are lithologically similar to the older Oligocene rocks; but the Yaquina Formation (Harrison and Eaton, 1920; and Vokes and others, 1949), which crops out near the coast in the southwestern part of the map area, consists of massive to crossbedded tuffaceous and arkosic sandstone and siltstone (fig. 7).

Fourteen surface samples of strata of late Eocene to late Oligocene age in the map area range in density from 1.72 to $2.36 \mathrm{~g}$ per $\mathrm{cm}^{3}$ and average about $2.1 \mathrm{~g}$ per $\mathrm{cm}^{3}$.

Marine strata of Miocene age are restricted to the Newport and Tillamook structural embayments, and to a broad downwarp along the lower reaches of the Columbia River. These strata consist predominantly of marine siltstone and mudstone of early Miocene 


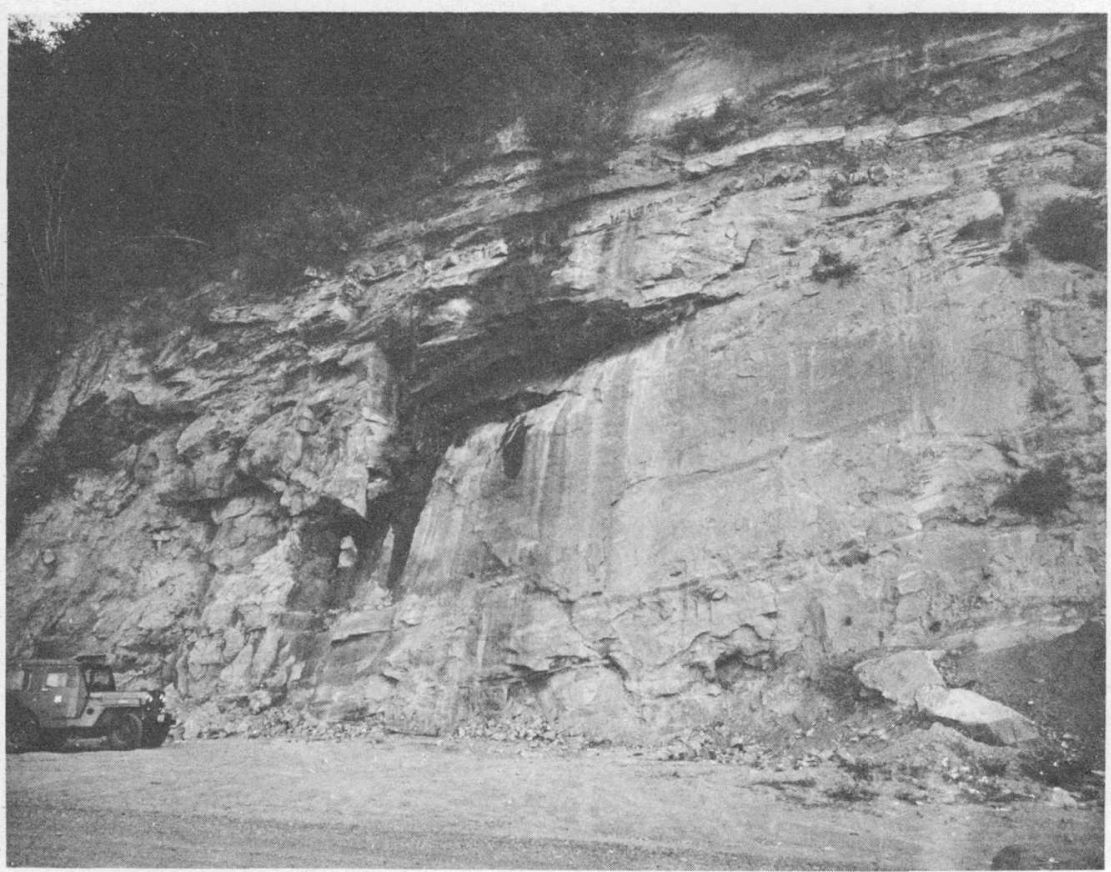

Figure 7.-Massive arkosic sandstone of the Yaquina Formation of late Oligocene age. Quarry on north bank of the Yaquina River, about 4 miles southeast of Newport, Oreg.

age and nearshore massive to thin-bedded fine- to medium-grained arkosic and tuffaceous sandstone and siltstone of middle Miocene age. Intercalated beds of water-laid ash as much as 10 feet thick are common, and basaltic sandstone and conglomerate derived from contemporaneous volcanism occur in the upper part of the sequence.

In the Newport embayment, more than 3,500 feet of organic-rich massive to poorly bedded mudstone conformably overlies the Yaquina Formation. These beds, originally called the Nye Shale, were named and described by Smith (1926, p. 269) and Schenck (1927, p. 450-459) but were later called the Nye Mudstone by Vokes and others (1949), who considered them early Miocene in age. The sandstone and siltstone strata of predominantly middle Miocene age which crop out along the coast are referred to the Astoria Formation (Howe, 1926) and are more than 1,000 feet thick. Densities measured on eight surface samples of typical strata of Miocene age range from 1.52 to $2.18 \mathrm{~g}$ per $\mathrm{cm}^{3}$ and average about $1.9 \mathrm{~g}$ per $\mathrm{cm}^{3}$.

\section{BASALT FLOWS AND BRECCIAS}

Throughout much of the northern part of the map area, thick columnar-jointed flows of dark-gray fine-grained basalt uncon- 


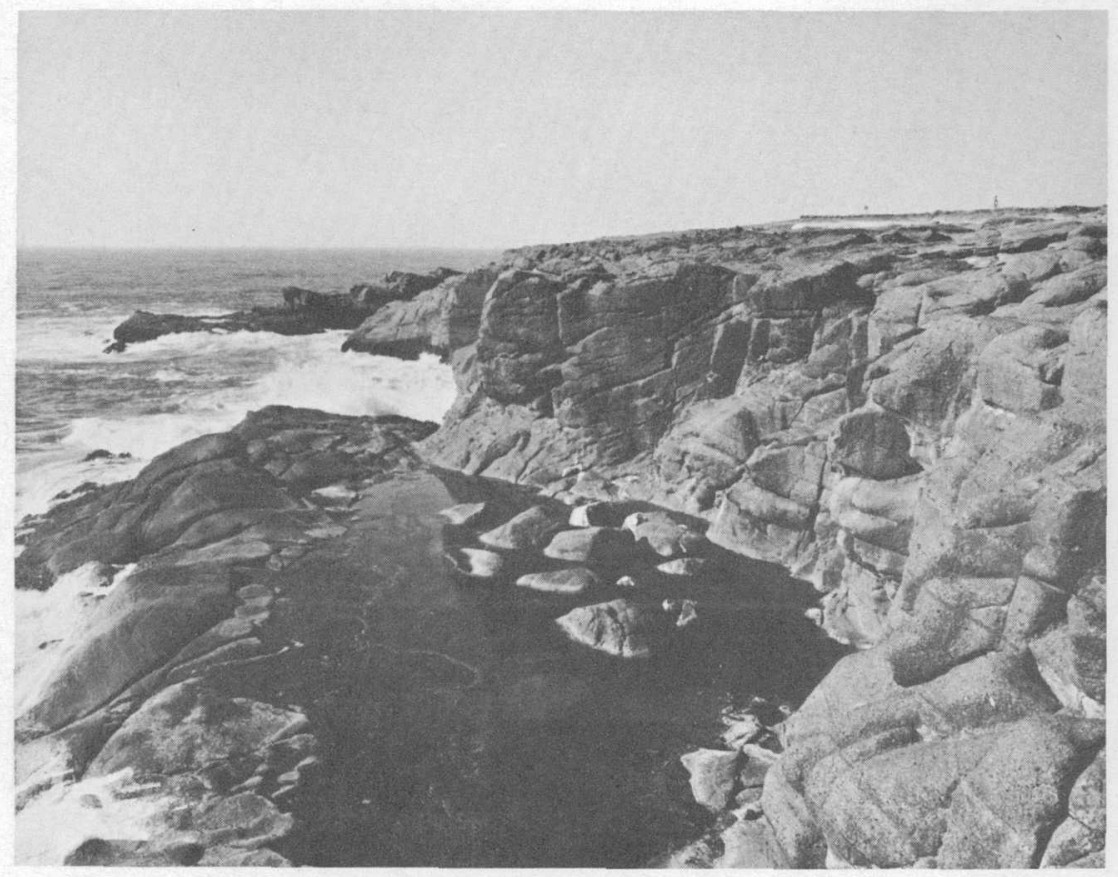

Figure 8.-Marine water-laid fragmental basaltic debris of late(?) Miocene age. Government Point, Oregon coast.

formably overlie marine strata principally of Oligocene age. These flows are correlative with the Yakima type of the Columbia River Basalt of Waters (1961). Basalt flows and breccia of similar composition were erupted from numerous local centers near the present coast line and form many of the prominent headlands north of Newport. In places, pillow flows, breccia, and fragmental debris (fig. 8) from these local vents overlie marine strata of the Astoria Formation. These volcanic rocks are tentatively assigned a late(?) Miocene age because in places they unconformably overlie middle Miocene marine strata. Density measurements on 20 surface samples of these rocks indicate a range from 2.31 to $2.98 \mathrm{~g} \mathrm{per} \mathrm{cm}^{3}$ and an average of about $2.8 \mathrm{~g}$ per $\mathrm{cm}^{3}$.

The Columbia River Basalt is more than 1,000 feet thick along the Columbia River in the northern part of the map area; there it rests on a maturely eroded surface of Tertiary sedimentary rocks. The basalt is dark gray to black, hard and dense, and commonly vesicular near the top of individual flows. Pillow structures and thick piles of volcanic breccia are common in exposures near the coast both 
where subaerial flows poured into the sea and where basalt was extruded on the ancient sea floor.

\section{GABBROIC AND ALKALIC INTRUSIVE ROCKS}

Gabbroic and alkalic hypabyssal intrusive bodies that probably were emplaced in late(?) Miocene and late Eocene(?) time, respectively, crop out extensively throughout the southern part of the map area. These rocks occur generally as sheetlike intrusions that range in attitude from nearly flat to vertical. The thicker gabbroic bodies are essentially horizontal and average 400-500 feet in thickness, but locally they are more than 800 feet thick. Erosional remnants of gabbroic sills cap many of the flat-topped mountains, such as Mount Hebo, Saddleback Mountain, Laurel Mountain, and Marys Peak (pl. 1). Density measurements made on 46 surface samples of gabbroic rocks range from 2.64 to $2.97 \mathrm{~g}$ per $\mathrm{cm}^{3}$ and average about $2.8 \mathrm{~g}$ per $\mathrm{cm}^{3}$.

Each of the thick gabbroic sills comprises a gradational sequence that includes basalt in the chilled border facies and granophyric gabbro and granophyric diorite in the main body. Irregular masses of a pegmatitic facies of the gabbroic rocks and cross-cutting veins of quartz-feldspar micropegmatite are less abundant.

Alkalic rocks probably make up less than 5 percent of the intrusive suite in the Oregon Coast Range. In the southwestern part of the map area, nepheline syenite porphyry forms the 200-300-foot-thick sill that caps Table and Cannibal Mountains and forms the stock at Blodgett Peak. Camptonite forms the stock at Cougar Mountain, just south of lat $45^{\circ} \mathrm{N}$. (pl. 1), and is present in other sills and dikes in the same general area.

\section{NONMARINE FLUVIATILE AND LACUSTRINE DEPOSITS}

Along the south side of the Columbia River in the extreme northwestern part of the map area, a sequence of massive crossbedded quartzose sandstone and siltstone of late(?) Miocene and Pliocene age overlies the Columbia River Basalt. These rocks are more than 500 feet thick and contain much partially carbonized wood and carbonaceous debris. The rocks are in part equivalent in age to the fluviatile and lacustrine sediments that fill the structural basins - underlying the Tualatin Valley and the downwarp east of the Portland Hills. This ancient basin fill, which is referred in part to the Troutdale Formation (Hodge, 1933; Treasher, 1942; and Trimble, 1963), is more than 1;000 feet thick in the Tualatin Valley and consists of semiconsolidated carbonaceous claystone, siltstone, and fine-grained sandstone. 
Locally along the west flank of the Portland Hills anticline, gray porous olivine basalt-the Boring Lava of Treasher (1942), who assigned it a late Pliocene or early Pleistocene age ${ }^{4}$-overlies strata of the Troutdale Formation. Along the eastern margin of the map in the Willamette Valley, reddish-brown decomposed gravels and interbedded sand and silt underlie widespread deposits of light-brown Willamette Silt of late Pleistocene age (Allison, 1953). Also included in this unit are silts, sands, and gravels that occur along the major stream courses, dune and beach sand and bay fill in the coastal areas, and a few large areas of landslide debris.

\section{REFERENCES}

Allison, I. S., 1953, Geology of the Albany quadrangle, Oregon: Oregon Dept. Geology and Mineral Industries Bull. 37, 18 p.

Baldwin, E. M., Brown, R. D., Jr., Gair, J. E., and Pease, M. H., Jr., 1955, Geology of the Sheridan and McMinnville quadrangles, Oregon: U.S. Geol. Survey Oil and Gas Inv. Map OM-155, scale 1:62,500.

Diller, J. S., 1898, Description of the Roseburg quadrangle [Oregon]: U.S. Geol. Survey Geol. Atlas, Folio 49.

Harrison and Eaton [firm], 1920, Report on investigation of oil and gas possibilities of western Oregon: Oregon Bur. Mines and Geology, Min. Res. Oregon, v. 3 , no. 1 , p. 3-37.

Hodge, E. T., 1933, Age of Columbia River and lower canyon [abs.]: Geol. Soc. America Bull., v. 44, p. 156-57.

Howe, H. V., 1926, Astoria, mid-Tertic type of Pacific Coast: Pan-Am. Geologist, v. 45, p. 295-306.

Mallory, V. S., 1959, Lower Tertiary biostratigraphy of the California coast ranges: Tulsa, Okla., Am. Assoc. Petroleum Geologists, Bull. 416 p.

Peck, D. L., Griggs, A. B., Schlicker, H. G., Wells, F. G., and Dole, H. M., 1964, Geology of the central and northern parts of the Western Cascade Range in Oregon: U.S. Geol. Survey Prof. Paper 449. [In press.]

Schenck, H. G., 1927, Marine Oligocene of Oregon: California Univ. Dept. Geol. Sci. Bull., v. 16, no. 12, p. 449-60.

Smith, W. D., 1924, Petroleum possibilities of western Oregon: Econ. Geology, v. 19 , p. $455-65$.

1926, Physical and economic geology of Oregon; the Coast Range Province: Oregon Univ., Commonwealth Review, v. 8, p. 254-97.

Snavely, P. D., Jr., and Baldwin, E. M., 1948, Siletz River volcanic series, northwestern Oregon: Am. Assoc. Petroleum Geologists Bull., v. 32, p. 805-12.

Snavely, P. D., Jr., and Vokes, H. E., 1949, Geology of the coastal area between Cape Kiwanda and Cape Foulweather, Oregon: U.S. Geol. Survey Oil and Gas Inv. (Prelim.) Map 97, scale 1:62,500.

Snavely, P. D., Jr., and Wagner, H. C., 1963, Tertiary geologic history of western Oregon and Washington: Washington Div. Mines and Geology Rept. Inv. 22, 25 p.

\footnotetext{
- Recent work by Trimble (1963, p. 36-42) indicates that the Boring Lava is as young as late(?) Pleistocene in age.
} 
Stuart, D. J., 1961, Gravity study of crustal structure in western Washington: U.S. Geol. Survey Prof. Paper 424-C, art. 248, p. C273-C276.

Treasher, R. C., 1942, Geologic history of the Portland [Oregon] area: Oregon Dept. Geology and Mineral Industries Short Paper 7, $17 \mathrm{p}$.

Trimble, D. E., 1963, Geology of Portland, Oregon, and adjacent areas: U.S. Geol. Survey Bull. 1119, 119 p.

Turner, F. E., 1938, Stratigraphy and Mollusca of the Eocene of western Oregon: Geol. Soc. America Spec. Paper 10, 130 p.

Vokes, H. E., Myers, D. A., and Hoover, Linn, 1954, Geology of the west-central border area of the Willamette Valley, Oregon: U.S. Geol. Survey Oil and Gas Inv. Map OM-150, scale 1:62,500.

Vokes, H. E., Norbisrath, Hans, and Snavely, P. D., Jr., 1949, Geology of the Newport-Waldport area, Lincoln County, Oregon: U.S. Geol. Survey Oil and Gas Inv. (Prelim.) Map 88, scale 1:62,500.

Warren, W. C., Norbisrath, Hans, and Grivetti, R. M., 1945, Geology of northwestern Oregon west of Willamette River and north of latitude $45^{\circ} 15^{\prime}$ : U.S. Geol. Survey Oil and Gas Inv. (Prelim.) Map 42, scale 1:190,000.

Waters, A. C., 1961, Stratigraphic and lithologic variations in the Columbia River Basalt: Am. Jour. Sci., v. 259, p. 583-611.

Weaver, C. E., and others, 1944, Correlation of the marine Cenozoic formations of western North America [Chart 11]: Geol. Soc. America Bull., v. 55, p. 569-598.

Wells, F. G., and Peck, D. L., 1961, Geologic map of Oregon west of the 121st meridian: U.S. Geol. Survey Misc. Geol. Inv. Map I-325, scale 1:500,000.

Wilkinson, W. D., Lowry, W. D., and Baldwin, E. M., 1946, Geology of the St. Helens quadrangle, Oregon: Oregon Dept. Geology and Mineral Industries Bull. $31,39 \mathrm{p}$. 


\section{Geologic Interpretation of}

\section{Reconnaissance Gravity and}

\section{Aeromagnetic Surveys in \\ Northwestern Oregon}

By R. W. BROMERY and P. D. SNAVELY, JR.

CONTRIBUTIONS TO GENERAL GEOLOGY

G E O L O G I C A L S UR V E Y B U L L E T I N $1181-\mathrm{N}$

$A$ correlation between the geology and reconnaissance gravity and aeromagnetic surveys in the northern part of the Oregon Coast Range

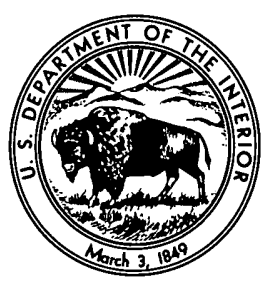





\section{CON'TENTS}

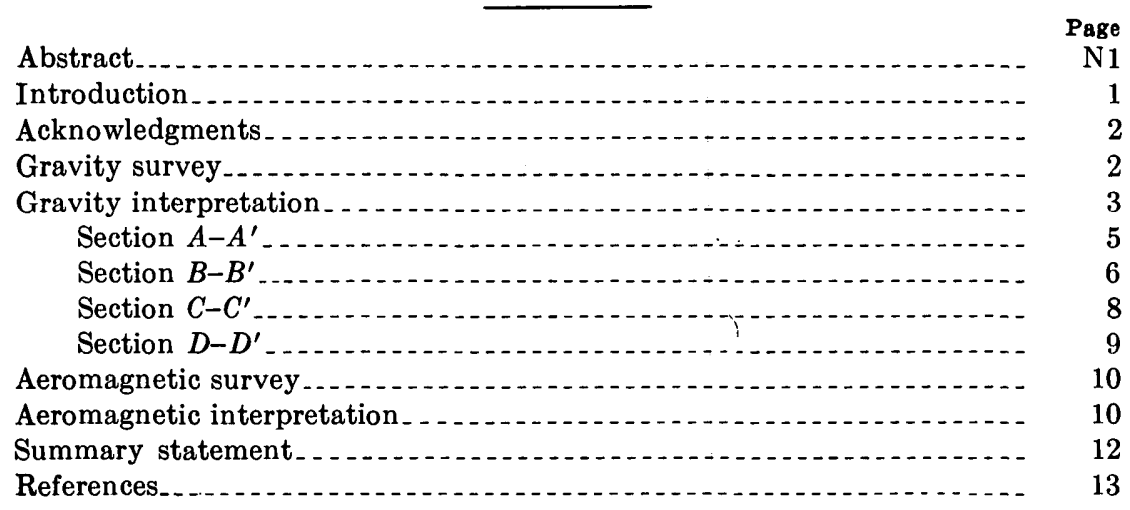

\section{ILLUSTRATIONS}

[Plates are in pocket]

Plate 1. Generalized geologic and simple Bouguer gravity map of northwestern Oregon.

2. Reconnaissance east-west aeromagnetic profiles, northwestern Oregon.

3. Reconnaissance aeromagnetic profile along the Oregon coast from Florence to Cannon Beach.

Figures 1-4. Two-dimensional interpretations: Page

1. Nehalem River basin gravity anomaly along section $A-A^{\prime}$. _- N6

2. Tualatin Valley gravity anomaly along section $B-B^{\prime} \ldots \ldots$

3. Newport embayment gravity anomaly along section $C-C^{\prime} \ldots$

4. Gravity anomaly along section $D-D^{\prime} \ldots \ldots$ 



\title{
CONTRIBUTIONS TO GENERAL GEOLOGY
}

\section{GEOLOGIC INTERPRETATION OF RECONNAISSANGE GRAVITY AND AEROMAGNETIC SURVEYS IN NORTHWESTERN OREGON}

\author{
By R. W. Bromery and P. D. Snavely, Jr.
}

\section{ABSTRACT}

Analyses of gravity and aeromagnetic data have proven useful in providing information on the thickness, depth of burial, and subsurface distribution of lower to middle Eocene volcanic rocks in northwestern Oregon.

Three broad gravity highs are shown on the Bouguer gravity map. Two highs are associated with surface and near-surface occurrences of the lower to middle Eocene volcanic rocks in the northern and central parts of the map area. The third broad gravity high, in the southwestern part of the map area, is interpreted as being produced by a major structural high of lower to middle Eocene volcanic rocks that are overlain by less than 5,000 feet of younger rocks. In the areas of these gravity highs, aeromagnetic data show sharp, high-amplitude magneticanomaly zones, typical of the magnetic expression of the lower to middle Eocene volcanic rocks.

Analyses of major gravity lows over the Tualatin Valley and the Nehalem River basin indicate that the sedimentary rock sequence younger than the lower to middle Eocene volcanic rocks attains thicknesses of 20,000 feet and 10,000 feet, respectively, in the central parts of these basins. The thickness of these rocks in the Nehalem River basin, as interpreted from the gravity data, is in close agreement with stratigraphic data obtained from a test well drilled near the line of section. Interpretations of aeromagnetic and gravity data across the Newport and Tillamook embayments suggest that this sedimentary rock sequence is 12,000 feet and 8,000 feet thick, respectively, in the central parts of these embayments; surface geology supports these interpretations. A steep east-sloping gravity gradient along the entire east margin of the map area suggests that major faulting delimits the west edge of the Willamette Valley downwarp or graben.

\section{INTRODUCTION}

Gravity and aeromagnetic data have proven to be a valuable aid in the interpretation of the tectonic framework of the Coast Ranges of western Oregon and Washington. This region is underlain by a sequence of lower to middle Eocene volcanic rocks whose structures are reflected in part in the younger strata. The great thickness and wide areal distribution of this volcanic sequence, together with its pronounced contrast in magnetization and density as compared to 
the overlying sedimentary rocks, make the top of the sequence an excellent surface to map geophysically.

Because of the large size and geological complexity of the area with which this report is concerned, as statistically valid-sampling of the pertinent physical properties of the rock units giving rise to gravity and magnetic anomalies is virtually impossible. Therefore, by necessity, assumptions based on broad regional considerations were made concerning the density and thickness of some stratigraphic units and the nature (composition and density) of the pre-Eocene rocks.

\section{ACKNOWLEDGMENTS}

The assistance of D. J. Stuart, J. E. Carlson, and W. T. Kinoshita in performing the gravity surveys is gratefully acknowledged. The report was appreciably improved by the critical reviews of $D$. R. Mabey, G. E. Andreasen, and T. H. McCullob.

\section{GRAVITY SURVEY}

Approximately 750 gravity stations were established in the map area during the field seasons of 1958,1959 , and 1960. The station distribution is approximately one station for every 10 square miles except between lat $45^{\circ} 15^{\prime} \mathrm{N}$. and $45^{\circ} 45^{\prime} \mathrm{N}$. and long $123^{\circ} 30^{\prime} \mathrm{W}$. and $123^{\circ} 35^{\prime}$ W. (pl. 1). In this area the paucity of roads and elevation control, combined with extremely rugged terrain, accounts for the lower station density. All gravity measurements were made with two Worden gravimeters having sensitivities of 0.4738 and 0.4909 mgal per scale division, respectively. All instrument readings were corrected for drift and reduced to sea level datum after assuming a density of $2.67 \mathrm{~g}$ per $\mathrm{cm}^{3}$ (grams per cubic centimeter) for the material between the station elevation and sea level. The observed gravity values were referred to an absolute value of 980.5148 gals (Behrendt and Woollard, 1961) at a base station at the Eugene, Oreg., airport. The theoretical sea-level gravity at each station was determined from the table of values of theoretical gravity on the international ellipsoid by Lambert and Darling (Nettleton, 1940, p. 139-43). The simple Bouguer anomalies are contoured at a contour interval of $5 \mathrm{mgal}$ (pl. 1).

The majority of gravity stations in the map area are at bench marks. Elevations for approximately 30 stations in the vicinity of Laurel and Ball Mountains in the west-central part of the map area were determined by altimetry; these elevations may be in error by as much as 20 feet and thus may produce an elevation-correction error of as much as $1.2 \mathrm{mgal}$. Topographic corrections were made for a selected group of stations within the map area. The largest topographic correction, $8 \mathrm{mgal}$, was obtained in the rugged highlands near the coast in the northern part of the map area. However, as 
the majority of stations have corrections of less than 2 mgal, topographic corrections were not made for all of the stations, and no topographic corrections are included in the map data.

\section{GRAVITY INTERPRETATION}

In this report, interpretations of the gravity anomalies are based on the assumption that the anomalies are produced by the configuration of the thick lower to middle Eocene volcanic sequence that underlies the Oregon Coast Range. It is possible that density contrasts deep within the crust may contribute to these gravity anomalies. Vertical and lateral lithologic variations in the lower to middle Eocene volcanic sequence could markedly affect its density and further complicate the interpretation of the gravity data.

The average density of surface samples of the upper Eocene through Pliocene sedimentary sequence is estimated to be $2.1 \mathrm{~g}$ per $\mathrm{cm}^{3}$ on the basis of 22 representative samples. Inasmuch as the density of the sedimentary rocks was measured on surface samples, some of which were slightly weathered, and inasmuch as the densities of clastic sediments are known to increase with depth of burial, the calculated density of 2.1 is unquestionably low. The expected increase in density of water-saturated sedimentary rocks at depth, combined with the effect of interstratified high-density basalts and gabbroic intrusives (average, $2.7 \mathrm{~g}$ per $\mathrm{cm}^{3}$ ), makes an average density of 2.4 g per $\mathrm{cm}^{3}$ a reasonable assumption for the post-Tyee sequence. The density of the Tyee Formation also averages about $2.4 \mathrm{~g} \mathrm{per} \mathrm{cm}^{3}$ (58 samples), and, therefore, the entire post-Siletz River sedimentary and volcanic sequence is assumed to average $2.4 \mathrm{~g}$. per $\mathrm{cm}^{3}$. As the density of the Siletz River Volcanic Series averages about $2.8 \mathrm{~g}$ per $\mathrm{cm}^{3}$ (42 samples), a density contrast of $0.4 \mathrm{~g}$ per $\mathrm{cm}^{3}$ between the Siletz River volcanics and the overlying rocks has been used in gravity calculations. A density contrast of $0.1 \mathrm{~g}$ per $\mathrm{cm}^{3}$ between the Siletz River volcanics and the balance of crustal rocks underlying the Siletz River has been used in calculations because an average density of $2.7 \mathrm{~g}$ per $\mathrm{cm}^{3}$ was obtained for the exposed argillite and graywacke that underlie the lower to middle Eocene rocks in the Olympic Peninsula north of the map area. As this density is approximately the same as the general average density for crustal marerial, rocks having a density value of $2.7 \mathrm{~g}$ per $\mathrm{cm}^{3}$ are assumed to represent the remaining crustal rocks in sections $A-A^{\prime}$ to $D-D^{\prime}$.

The most significant features of the gravity map are (1) three broad gravity highs, (2) a major gravity low, (3) a steep east-sloping gravity gradient along the east margin of the map area, and (4) a pronounced gravity high that projects into the extreme northeastern part of the map. 
The two broad gravity highs in the north-central and west-central parts of the map area are associated with the surface and near surface occurrences of the thick high-density Tillamook and Siletz River Volcanic Series, respectively.

The large gravity high near the coast in the southwestern part of the map is interpreted as being produced by the Siletz River Volcanic Series at moderate depth (less than 1 mile). Although upper Eocene volcanic rocks, having an average measured density of $2.8 \mathrm{~g} \mathrm{per} \mathrm{cm}^{3}$, crop out here, this sequence is less than 1,500 feet thick and probably contributes little to the gravity anomaly.

The major gravity low in the northeastern part of the map area centers over the structural downwarp of the Tualatin Valley. In this downwarp, available subsurface data suggest that more than 15,000 feet of predominantly sedimentary rocks overlie the lower to middle Eocene volcanic rocks. Less prominent gravity lows along the coast in the vicinities of Astoria, Tillamook, and Newport coincide roughly with known thick accumulations of post-middle Eocene sedimentary rocks in structural embayments.

The steep east-sloping gravity gradient along the entire east margin of the map area is caused by a rapid thickening of post-middle Eocene sedimentary rocks off the east flank of the Coast Range uplift. The steepness and linear trend of this gradient suggests that it is the result of major faulting that in general would delimit the west edge of the Willamette Valley downwarp or graben.

The large gravity high that projects into the extreme northeastern part of the map is the southward extension of a major gravity anomaly underlain by the-lower to middle Eocene volcanic rocks that crop out in the Willapa Hills of southwestern Washington (Stuart, 1961, p. 273-276).

The large northeast-trending exposure of lower to middle Eocene volcanic rocks immediately west of Corvallis does not produce the characteristic gravity high associated with the other large outcrops of volcanic rocks of this age. The inferred depositional history of this volcanic unit implies a thinning of the sequence eastward toward the margin of the geosyncline and a concommitant increase in detrital volcanic debris. Therefore, the lack of a major gravity expression probably results from a combination of eastward thinning of the flows and an increase in thickness of sedimentary interbeds.

To analyze the gravity profiles properly in relation to distributions of mass ator near the surface of the crust, the regional gravity gradient must be removed. The following method was used to obtain an objective approximation of the regional gravity gradient. A square grid having a spacing of 10 miles was constructed covering both the map area and the area along the west margin of the Cascade Range 
where a few additional gravity stations were available. The size of the grid was selected to minimize the effect of those local gravity anomalies whose areal extent is less than 100 square miles. Average values were computed for the grid intersections, and these averaged regional gravity values were contoured. The resulting map indicates that the regional gravity field is flat along the western part of the map area and slopes uniformly down to the east at $0.7 \mathrm{mgal}$ per mile along the eastern part of the map area starting at approximately long $123^{\circ} 30^{\prime} \mathrm{W}$. Thinning of the lower to middle Eocene volcanic sequence toward the east and thickening of the sedimentary rocks of the Willamette Valley downwarp partially contribute to this east-sloping gravity gradient. However, it is believed that this change in the regional geology affects the magnitude but does not greatly alter the overall character of the computed regional gravity field. The map area lies within the transition zone between the deep Pacific basin and the high Cascade Range, and the variation in crustal thickness that compensates for this marked topographic difference undoubtedly contributes to the regional gravity gradient.

Utilizing known geologic data and assumptions based on these data, two-dimensional gravity profiles were calculated across four pronounced gravity features.

\section{SECTION $A-A^{\prime}$}

Section $A-A^{\prime}$ extends north-northeastward from Kings Mountain, on the structural high underlain by the Tillamook Volcanic Series, across the Nehalem River basin (Warren and Norbisrath, 1946) to a point northwest of the town of Clatskanie (pl. 1).

Inasmuch as The Texas Co. Clark and Wilson test well that was drilled near the line of this section penetrated a thickness of nearly 10,000 feet of middle(?) to upper Eocene sedimentary and volcanic rocks and Oligocene strata, two analyses of the gravity profile along this line of section were made to test the validity of the assumptions regarding the densities and gross distributions of the subsurface rock units.

In the first analysis (fig. $1 A$ ), no density contrast was assumed between the Tillamook Volcanic Series and the buried pre-Tertiary rocks. On this basis, a thickness of 5,000 feet of post-Tillamook rocks in the central part of the Nehalem River basin was calculated.

In the second analysis (fig. $1 B$ ), the Tillamook Volcanic Series was assumed to be 20,000 feet thick and $0.1 \mathrm{~g}$ per $\mathrm{cm}^{3}$ denser than the underlying pre-Tertiary rocks. This analysis indicated a thickness for the post-Tillamook rocks of approximately 8,000 feet in the central part of the Nehalem River basin. This thickness more closely agrees with the data from The Texas Co. well. Thus, this con- 


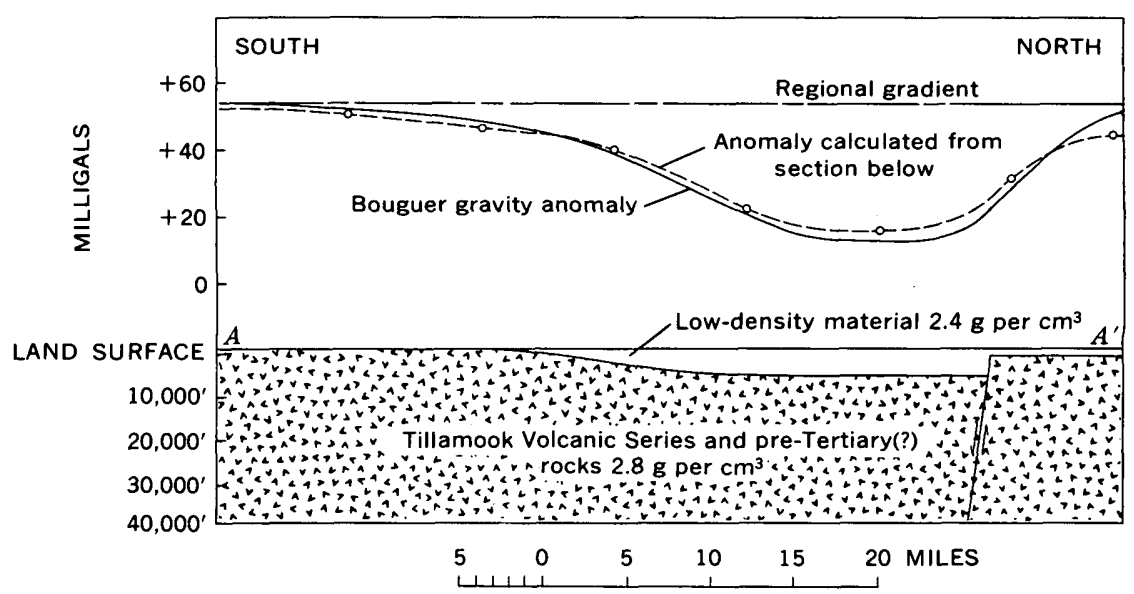

$\boldsymbol{A}$

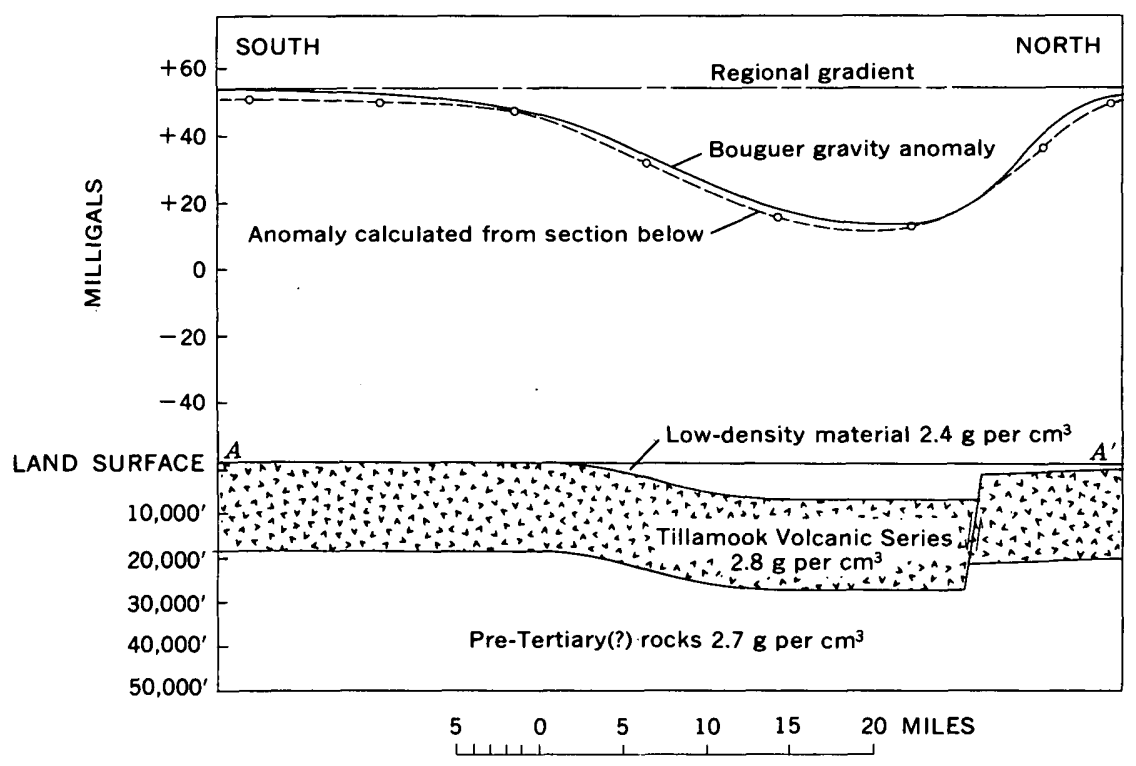

$B$

Figure 1.-Two-dimensional interpretations of the Nehalem River basin gravity anomaly along section $A-A^{\prime} . \quad A$, First interpretation; $B$, alternate interpretation.

trolled set of analyses lends credence to the belief that the dense lower to middle Eocene volcanic rocks are underlain by less dense Cretaceous(?) rocks.

\section{SECTION $B-B^{\prime}$}

Section $B-B^{\prime}$. extends east-southeastward from Kings Mountain in the structurally high area underlain by the Tillamook Volcanic 
Series, across the Tualatin Valley structural downwarp, and to a point near Portland (pl. 1).

The analysis of the profile along this line of section (fig. 2) assumes that the Tillamook Volcanic Series is 20,000 feet thick in the highland area at the west end of the section and thins eastward to 15,000 feet. A density contrast of $0.1 \mathrm{~g}$ per $\mathrm{cm}^{3}$ between the volcanic sequence and the underlying, less dense older rocks was also assumed in this section. The analysis indicates that the post-Tillamook sequence is approximately 25,000 feet thick near the central part of the downwarp. As the gravity low is nearly circular and of small diameter, a three-dimensional analysis would be more appropriate and would indicate a somewhat thicker section of post-Tillamook rocks within a deeper, but smaller diameter basin. This conspicious circular gravity low may reflect a major change in crustal density associated with a volcano-tectonic depression, rather than a significant increase in the thickness of post-middle Eocene sedimentary rocks.

The steep gravity gradient along the west edge of the Tualatin Valley shows that the top of the Tillamook Volcanic Series dips steeply to the east, thus suggesting a normal fault that downdropped these volcanic rocks to the east. Movement along this fault may be responsible in part for the formation of the basin in which a thick sequence of sedimentary and volcanic rocks accumulated. The rise in the gravity near the east end of the section reflects the presence of the

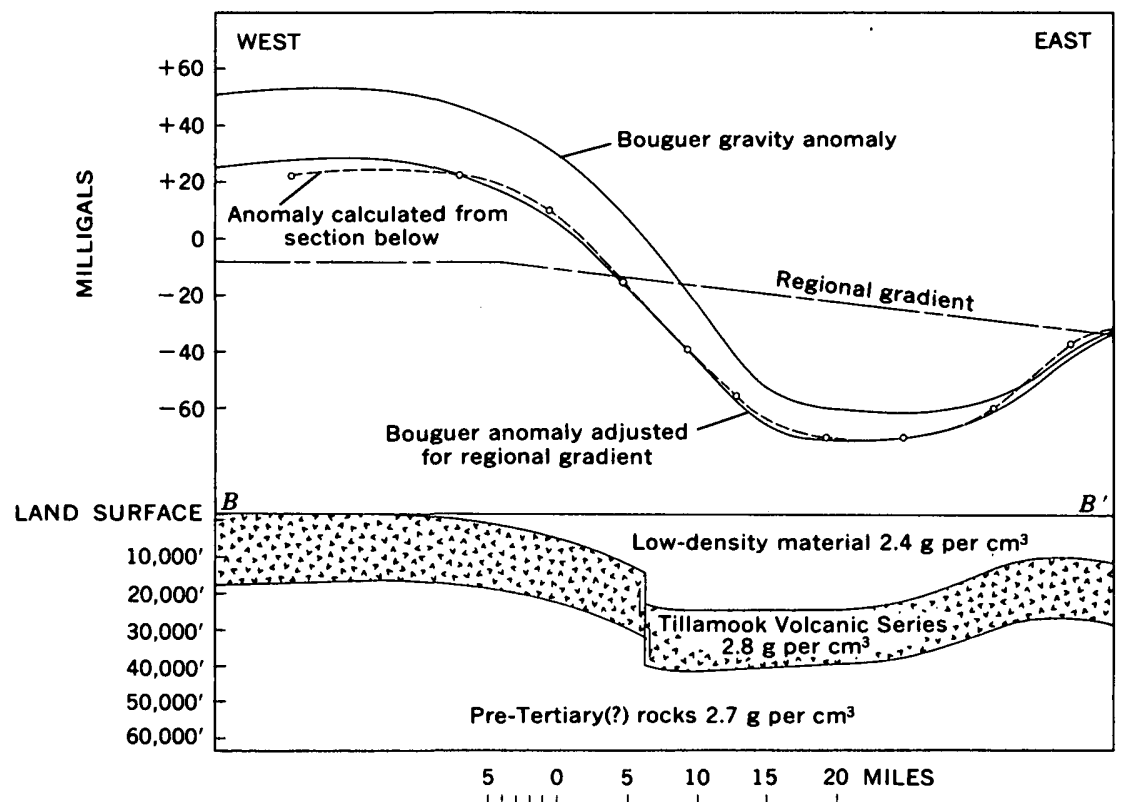

Figure 2.-Two-dimensional interpretation of the Tualatin Valley gravity anomaly along section $B-B^{\prime}$. 
Tillamook Volcanic Series nearer the surface under the Portland Hills anticline.

\section{SECTION $C-C^{\prime}$}

Section $C-C^{\prime}$ extends from Heceta Head, which is underlain by upper Eocene basalt flows, generally northward across the thick sedimentary sequence of the Newport embayment to Ball Mountain in the rugged highlands formed by the lower to middle Eocene Siletz River Volcanic Series (pl. 1). Surface geologic data from along the Yaquina River, which crosses the line of section near the middle, indicates that 10,000-15,000 feet of sedimentary rocks overlie the Siletz River Volcanic Series. Calculations based on the assumption of a thickness of 20,000 feet for the rocks of the Siletz River Volcanic Series resulted in only about 8,000 feet of sedimentary rocks in the Newport embayment. A thickness of $15 ; 000$ feet (fig. 3) had to be assumed for the Siletz River Volcanic Series to obtain a sedimentary sequence of a thickness in agreement with surface geologic evidence. Assuming a lower density, rather than a reduction in thickness, for the post-Siletz River rocks would have led to similar results.

One of the largest and most interesting gravity features is at the south end of this section. Although the apex of the gravity high coincides in part with the areal outcrop of upper Eocene alkalic basalt, geologic evidence indicates that the total thickness of these flows is only about 1,500 feet and could not have produced this large gravity high. Assuming that the Siletz River Volcanic Series is uniformly thick along the line of section, the analysis indicates that south of Newport these volcanic rocks rise abruptly to within less than 5,000

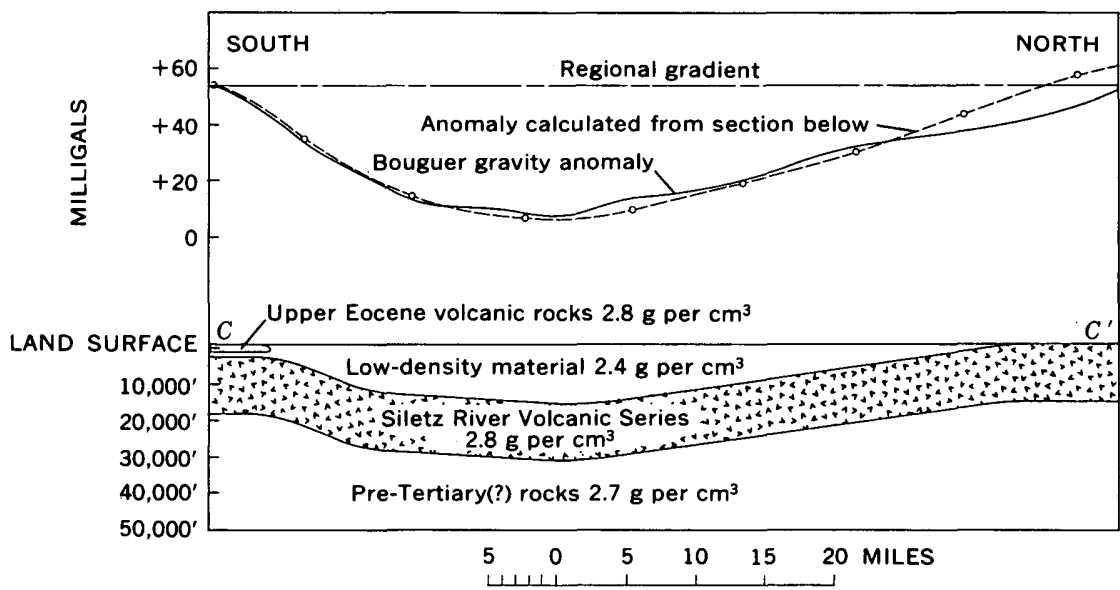

FIGURE 3.-Two-dimensional interpretation of the Newport embayment gravity anomaly along section $C-C^{\prime}$. 
feet of the surface. Therefore, this arcuate gravity high is interpreted as a near-surface expression of the Siletz River Volcanic Series along a major structural high that lies beneath the widespread unconformity at the base of upper Eocene volcanic and sedimentary rocks in this area. Although surface geologic mapping of the rocks above the unconformity does not discern this structural high, both magnetic and gravity data indicate its presence.

\section{SECTION $D-D^{\prime}$}

Section $D-D^{\prime}$ extends from the gravity high north of Heceta Head generally eastward across the Coast Range uplift to a point in the Willamette Valley northeast of Eugene (pl. 1). Along this line of section, rocks of the Siletz River Volcanic Series in the vicinity of Heceta Head are buried at a shallow depth (fig. 4). Eastward the thickness of the overlying sedimentary rocks increases slightly along the line of section as far as the west edge of the Willamette Valley. In the intervening area there is in general a correlation between gravity highs and folds mapped at the surface. Near the east end of the section, a steep gravity gradient that slopes eastward toward the Willamette Valley probably indicates a rapid thickening of postSiletz River sedimentary rocks. This steep gradient is part of the pronounced north-trending gravity gradient that extends the entire length of the map. The steepness and linear trend of this gradient suggests the presence of a major fault along the west edge of the Willamette Valley downwarp or graben.

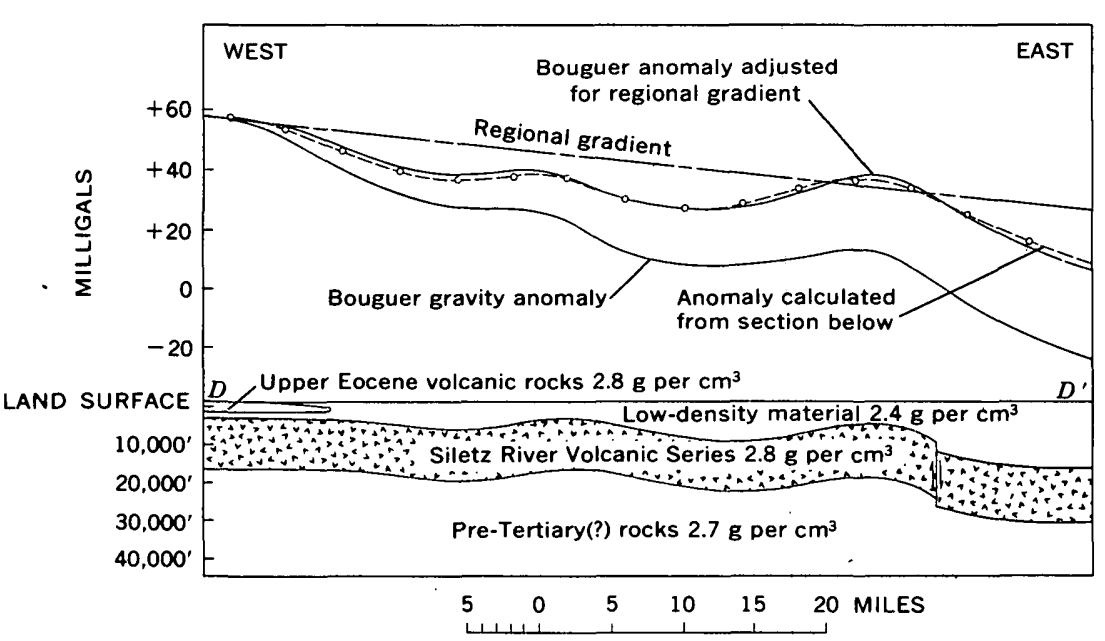

Figure 4.-Two-dimensional interpretation of the gravity anomaly along section $D-D^{\prime}$. 


\section{AEROMAGNETIC SURVEY}

Eighteen reconnaissance total-intensity aeromagnetic traverses - were flown in 1954 and 1959 to gain information on the distribution and depth of burial of magnetic rock units in the Oregon Coast Range. The :aeromagnetic study was made as an outgrowth of more detailed aeromagnetic surveys in southwestern Washington (Henderson and others, 1958) which show a close correlation between surface and subsurface distribution of Eocene volcanic rocks and magnetic anomalies. The aeromagnetic traverses were flown by the Geological Survey along selected flight lines at a barometric flight elevation of 4,000 feet. The magnetic measurements were made using a continuously recording modified $\mathrm{AN}-\mathrm{ASQ} / 3 \mathrm{~A}$ airborne magnetometer. The locations of the flight paths were recorded by a continuous $35 \mathrm{~mm}$ strip-film camera. The magnetic measurements were compiled as magnetic profiles (pls. 2,3 ) at the scale of the geologic map $(1: 500,000)$ (pl. 1).

Sixteen of the magnetic traverses that were flown in 1954 and 1959 are shown on plates 2 and 3 ; the remaining two magnetic traverses are outside the report area and are not shown. The nine magnetic traverses that were flown in 1954 (profiles I, II, IV, V, VII, IX, XI, XV, XVI) have been placed on open file (Bromery, 1957). Profile I, shown on plate 3, extends from near the town of Florence just south of the map area north along the coast to Cannon Beach near lat $46^{\circ} 00^{\prime} \mathrm{N}$. (see pl. 1). Profiles II thru XVI were flown from the coast eastward to points near the foothills of the Cascade Range. These east-west profiles have been nested and referenced to long $123^{\circ} 15^{\prime}$ (pl. 2), but they are not tied to a northsouth geographic reference.

\section{AEROMAGNETIC INTERPRETATION}

Measurements of magnetic susceptibilities were made on a few samples from the various volcanic rocks of northwestern Oregon. These measurements suggest that the rocks of the Siletz River Volcanic Series are, in general, of higher susceptibility than the other volcanic rocks of the map area.

The magnetic susceptibilities of 54 samples (measurements by William Huff, U.S. Geological Survey) from the various volcanic rocks within the map area range as follows: The Siletz River volcanic rocks, $0.2 \times 10^{-3}$ to $6.25 \times 10^{-3}$ cgs (centimeter-gram-second) units; upper Eocene volcanic rocks, $0.46 \times 10^{-3}$ to $2.02 \times 10^{-3} \mathrm{cgs}$ units; Miocene volcanic rocks, $0.15 \times 10^{-3}$ to $2.01 \times 10^{-3} \mathrm{cgs}$ units; and upper(?) Miocene intrusive siils, $0.20 \times 10^{-3}$ to $2.60 \times 10^{-3} \mathrm{cgs}$ units. In each group the greater number of samples have susceptibilities near the 
middle and upper parts of their respective ranges. The low values of the ranges may be a result of weathering in some of the groups.

In the Oregon Coast Range, high-amplitude magnetic anomalies are underlain at or near the surface by lower to middle Eocene volcanic rocks (Siletz River and Tillamook Volcanic Series). With the exception of profile II, the high-amplitude magnetic anomalies along the east edge of the map area result from the eastward thickening of the middle to upper Tertiary volcanic sequence that underlies the Cascade Range. The magnetic anomaly at the east end of profile II is caused by a thick sequence of exposed upper Eocene volcanic rocks, but it may in part be an expression of the underlying lower to middle Eocene volcanic rocks.

The four areas of low-amplitude magnetic anomalies that have been delineated on plates 2 and 3 reflect deep burial of the lower and middle Eocene volcanic sequence. The two arcuate areas of low-amplitude magnetic anomalies at the west ends of profiles IV and V, and profiles XII and XIII are, in general, coincident with the thicker sections of sedimentary rocks in structural embayments in the vicinities of Tillamook and Newport, respectively.

An analysis of the magnetic anomalies at the west end of profile XIII near the town of Newport indicates that rocks of the Siletz River Volcanic Series are buried to a depth of at least 12,000 feet below the land surface. This depth is in agreement with the depth of burial calculated along gravity section $C-C^{\prime}$. Surface geology indicates a thickness of 10,000-15,000 feet of strata above the Siletz River Volcanic Series near Newport.

At the west end of profile IV in the vicinity of Tillamook, an analysis of the magnetic anomalies indicates that the rocks of the Tillamook Volcanic Series are buried 7,000-8,000 feet below the surface. Although detailed geologic mapping is not available in this area, the thickness of exposed sedimentary rocks that overlie the Tillamook Volcanic Series about 10 miles south of Tillamook along Beaver Creek was estimated by Warren and others (1945) to be approximately 8,000 feet.

On profile 1 also, the Newport and Tillamook embayments are displayed as areas of low-amplitude magnetic anomalies. A magnetic high near the middle of the Tillamook embayment on this profile probably reflects a structural nose of Tillamook volcanics that extends into the embayment from the east. This high is also expressed in the gravity contours on plate 1 near lat $45^{\circ} 30^{\prime} \mathrm{N}$. near the coast.

The north-trending elongate belt of low-amplitude magnetic anomalies extending from profile VI to profile XVI (pl. 2) reflects a greater depth of burial of the Siletz River Volcanic Series off the east flank of the Coast Range uplift. Although this zone is well defined, these 
low-amplitude anomalies might extend farther eastward if it were not for the thick accumulation of volcanic rocks that are present at and below the surface along the west margin of the Cascade Range. The small magnetic anomalies within this low-amplitude magnetic belt may be caused by surface or near-surface intrusive bodies or by interbedded flows in the sedimentary sequence that overlies the Siletz River Volcanic Series.

The area of low-amplitude magnetic anomalies in the northern part of the map in general outlines the southeastern extension of the structural downwarp that extends from the mouth of the Columbia River through the Nehalem basin into the Tualatin Valley. This zone is separated from the elongate zone to the south by an area of higher amplitude magnetic. anomalies (see profile V, pl. 2) that may be caused by a subsurface thickening of basalt flows and breccia of late Eocene age and may, in part, be the surface expression of the Columbia River Basalt.

Within the area of high-amplitude magnetic anomalies are many sharp, positive and negative anomalies that are typical of the magnetic expression observed over the lower to middle Eocene volcanic sequence in the Oregon Coast Range. Examples of these pronounced anomaly patterns are in the western part of profile $\mathrm{X}$ and the central part of profile XIII. These anomalies are underlain by areas of outcrop of the Siletz River Volcanic Series and are interpreted as being caused by a strong anomalous remanent magnetization. Quantitative analysis of the magnetic anomalies on these profiles and other magnetic.profiles (Bromery, 1962) suggests that the remanent magnetization vector is steeply dipping and in some places reversed, and the horizontal component is oriented in east and west directions. This analysis is in close agreement with laboratory measurements made during a paleomagnetic study of this same volcanic sequence (Cox, 1957). The pronounced magnetic anomaly at the west end of profile XIV is characteristic of the magnetic expression of the Siletz River Volcanic Series. Depth computations based on this anomaly indicate that these volcanic rocks are buried 3,000-4,000 feet below the surface and that their structural configuration is similar to that of the Siletz River Volcanic Series west of Corvallis where it crops out extensively (see central part of profile XIII).

\section{SUMMARY STATEMENT}

The reconnaissance gravity and aeromagnetic surveys discussed in this report indicate clearly that certain geophysical methods can be exceedingly useful in analyzing the major structural features of northwestern Oregon. This region is particularly well suited geologically to treatment by these geophysical methods because the 
poorly exposed younger Tertiary sedimentary rocks are underlain by a thick sequence of lower Eocene volcanic rocks that have wide areal distribution, high total magnetization, and pronounced density contrast with the younger strata. Although only gross structural elements are delimited by this reconnaissance gravity and magnetic survey, it is anticipated that detailed ground surveys will provide much information on the continuity of smaller folds and faults that reflect structures involving the lower Eocene volcanic rocks.

A fruitful area for more detailed study would be the Willamette Valley where a Quaternary cover obscures the underlying Tertiary rocks and little is known of the subsurface structure. Northeasttrending folds and faults of the adjacent Oregon Coast Range intersect the Willamette Valley at oblique angles and could undoubtedly be delimited valleyward by these geophysical methods. Studies of the remanent magnetic properties of the individual flow units within the Siletz River Volcanic Series should prove useful as a means of correlating between isolated outcrops of these lower Eocene volcanic rocks.

\section{REFERENCES}

Behrendt, J. C., and Woollard, G. P., 1961, An evaluation of the gravity control network in North America: Geophysics, v. 26, no. 1, p. 57-76.

Bromery, R. W., 1957, Total-intensity aeromagnetic profiles of west-central Oregon: U.S. Geol. Survey open-file report, Oct. 1957, 4 sheets.

1962, Preliminary interpretation of an aeromagnetic map of the AlbanyNewport area, Oregon: U.S. Geol. Survey open-file report, Feb. 1962, 1 sheet.

Cox, Allan, 1957, Remanent magnetization of lower to middle Eocene basalt flows from Oregon: Nature, v. 179, no. 4561, p. 685-686.

Henderson, J. R., Jr., and others, 1958, Aeromagnetic maps of the Grayland, Aberdeen, Montesano, Malone, Rochester, Tenino, Yelm, Cape Shoalwater, South Bend, Willapa, Pe Ell, Adna, Centralia, and Onalaska quadrangles, Grays Harbor, Pacific, Lewis, and Thurston Counties, Washington: U.S. Geol. Survey Geophys. Inv. Maps GP-176 to GP-189.

Nettleton, L. L., 1940, Geophysical prospecting for oil, 1st`ed.: New York, McGraw-Hill Book Co., 444 p.

Stuart, D. J., 1961, Gravity study of crustal structure in western Washington: U.S. Geol. Survey Prof. Paper 424C, Art. 248, p. C273-C276.

Warren, W. C., and Norbisrath, Hans, 1946, Stratigraphy of upper Nehalem River Basin, northwestern Oregon: Am. Assoc. Petroleum Geologists Bull., v. 30 , p. $213-237$.

Warren, W. C., Norbisrath, Hans, and Grivetti, R. M., 1945, Geology of northwestern Oregon, west of Willamette River and north of latitude $45^{\circ} 15^{\prime}$ : U.S. Geol. Survey Oil and Gas Inv. (Prelim.) Map 42. 